\title{
EL ARQUETIPO DEL NIGROMANTE: MAGIA, MITO Y RITO EN SAN LORENZO DE EL ESCORIAL
}

\author{
Roberto Morales Estévez \\ (ESERP Madrid) \\ prof.rmorales@eserp.com
}

\section{RESUMEN}

La noche de San Juan de 1590 un clérigo nigromante y su paciente se dirigieron a los bosques que rodean El Escorial para realizar un interesante ritual mágico de invocación demoniaca con el fin de curar la impotencia. El análisis del mismo nos permitirá acercarnos al supuesto carácter mágico del Monasterio de San Lorenzo del Escorial, así como desentrañar el significado del ceremonial y todos sus elementos. De esta manera emergió el arquetipo del brujo y de su ceremonial que podremos relacionar con la tradición mítica europea.

PALABRAS CLAVE: Inquisición, Noche de San Juan, demonología, brujo, superstición.

\section{THE ARCHETYPE OF THE NECROMANCER: MAGIC, MYTH AND RITUAL IN SAN LORENZO DE EL ESCORIAL}

\begin{abstract}
On St John's Eve 1590 a necromancer clergyman and his patient headed to the woods surrounding the Escorial Monastery in order to perform an interesting magical ritual invoking the devil to heal erectile dysfunction. An analysis of that ritual will allow us to take a closer look to the alleged magical character of Monastery of San Lorenzo del Escorial, as well as to figure out the meaning of the ceremonial and its elements. This way the archetype of the wizard and his ceremonial shall arise and can be related with the European mythical tradition.
\end{abstract}

KEY WORDS: Inquisition, St John's Eve, El Escorial Monastery, demonology, wizard, superstition. 


\section{INTRODUCCIÓN}

Al amanecer del 23 de abril de 1590, dos forasteros se acercaron a las inmediaciones del Monasterio de San Lorenzo del Escorial. Se trata del clérigo nigromante Jaime Manobel y su paciente, aquejado de impotencia, Francisco Leal. Ambos se dispusieron, en la noche de San Juan, a realizar un extraño ritual para curar el mal que aquejaba a Leal que, según la creencia de la época, era producido por las brujas.

Manobel, nacido en el pueblo oscense de Sariñena en torno a 1556, era un clérigo aficionado al juego y la taberna de vida itinerante, en esencia, un pícaro ${ }^{1}$ lo que hizo que llegara a Madrid persiguiendo mejor fortuna buscando clientes a los que ofrecer sus supuestas dotes de sanación. Así conoció a Francisco Leal, carpintero natural de Valdemoro y vecino de la madrileña calle Mesón de Paredes.

El legajo en el que se relatan las andanzas de Manobel y Leal tiene como signatura AHN, Inq. Leg 90/6 del Archivo Histórico Nacional en Madrid, donde se custodian todos los expedientes que han sobrevivido a los avatares del tiempo del fondo inquisitorial de Toledo. Cirac Estopañán ${ }^{2}$ ya se ocupó del mismo de manera tangencial y refiriéndose al grimorio en los siguientes términos: "códice monstruoso de supersticiones [...] amalgama informe, a veces inteligible, de palabras hebreas, latinas y castellanas". Investigaciones posteriores, como la realizada por Carvajal González ${ }^{3}$, han demostrado que tanto el caso de Manobel como su grimorio eran de gran interés.

En otro artículo también me ocupé del grimorio que acompañaba al mago en sus acciones nigrománticas esbozando muy brevemente el ritual propiamente dicho, que es lo que justifica que vuelva ahora al legajo inquisitorial de Jaime Manobel ${ }^{4}$. En primer lugar, nos detendremos en el escenario, nada menos que los bosques que rodean el monasterio de San Lorenzo del Escorial. Frente al monasterio-palacio de geometrías renacentistas perfectas, emerge el bosque como antítesis. Por supuesto, la fecha del ritual no debe ser pasada por alto; la noche más mágica del año, la noche de San Juan, tan poderosa y evocadora antes como ahora. $\mathrm{Y}$, por último, el ritual propiamente dicho y todos los elementos que lo componen tales como el círculo mágico, el caballo o el árbol.

\footnotetext{
${ }^{1}$ Eva Lara, "Hechiceras celestinescas y nigromantes en la literatura del siglo XVI", en Señales, portentos y demonios. La magia en la literatura y la cultura española del Renacimiento, eds. Eva Lara y Alberto Montaner (Salamanca: Semyr), 367-432.

2 Sebastián Cirac Estopañán, Los procesos de hechicerías en la Inquisición de Castilla la Nueva: aportación a la historia de la Inquisición (Madrid: Instituto Jerónimo Zurita/CSIC, 1942), 23.

${ }^{3}$ Helena Carvajal González, “Cient sacras de pargamino': Un impreso 'sine notis’ desconocido del taller zaragozano de Jorge Coci en el Archivo Histórico Nacional”, Revista General De Información Y Documentación 29(2) (2019): 413-425.

${ }^{4}$ Roberto Morales, "Los grimorios y los recetarios mágicos: del mítico Salomón al clérigo nigromante", en Señales, portentos y demonios. La magia en la literatura y la cultura española del Renacimiento, eds. Eva Lara y Alberto Montaner (Salamanca: Semyr), 537-554.
} 


\section{EL MONASTERIO DE SAN LORENZO DEL ESCORIAL}

¿Por qué Manobel se desplazó a los bosques del Escorial? Mucho antes de la construcción del monasterio, al menos desde la Edad Media, el lugar era considerado por los lugareños como un paraje mágico, del cual se contaban innumerables leyendas. La presencia del imponente edificio solo hizo acrecentar esa fama.

Evidentemente, el "Rey prudente" no eligió el emplazamiento por dicha popularidad, sino porque el lugar cumplía las condiciones para situar su "única gran obra en lo referente a los Reales Sitios" ${ }^{\prime 5}$. Edificio y rey crearon un vínculo indisoluble 6 , lo que hace imposible entender el edificio sin atender a su creador.

No olvidemos que más que palacio y mausoleo, la función del mismo era monacal y, por tanto, era necesario un enclave rural como pretendía el monarca. Así, se propusieron varias ubicaciones como en la Sierra de Gredos, cercano al monasterio de Guisando ${ }^{7}$. El proyecto, al igual que otros, fue rechazado por el rey por hallarse demasiado lejos del resto de sus palacios, pues si su función monástica era la principal, ello no era óbice para obviar la palacial e incluso la museística ${ }^{8}$.

Como venimos reseñando, la notoriedad como enclave mágico planeó desde el primer momento sobre el edifico, excitando la imaginación de aquellos que visitaron el terreno del futuro monasterio, como la del Padre Fray José de Sigüenza ${ }^{9}$, que relató lo siguiente:

Acudieron todos el día señalado y partieron a Guadarrama muy alegres; vinieron a la villa del Escorial, desde allí caminamos juntos al sitio, comenzando á subir la cuesta; se levantó un aire furioso, como era en lo recio del invierno venía frí́simo, y soplaba con tanta furia que arrebató las bardas de la pared de una viñuela que estaba a mitad de la cuesta y dio con ellas en las caras de los que subían. De este viento despertado tan de repente en esta ocasión, y de otros muchos que en otras muy notables, como veremos en estos discursos, se han levantado, han congeturado algunos, no con poco fundamento, cuánto le ha pesado al demonio que se levantase una fábrica, donde como un alcázar fuerte, se le habían de hacer mucha guerra, sustentarse en ella lo que derriba en otras partes, y al tiempo que otros Príncipes destruyen las iglesias, asolan las religiones, burlan las reliquias, de los santos y todo cuanto tiene de bien y de piedad de la Iglesia [...] Parece que quiso en este torbellino entristecer o desmayar los ánimos de lo que venían á esplorar la tierra, para que dando a su Rey noticia de su

${ }^{5}$ Eloy Hortal, "La integración de los Sitios Reales en el sistema de la corte durante el reinado de Felipe IV", Libros de la Corte 6(8) (2014): 32.

${ }^{6}$ Para indagar en los motivos de la fundación del monasterio así como de la elección de su enclave y función es necesario acudirá a Agustín Bustamante García, La octava maravilla del mundo: Estudio histórico sobre el Escorial de Felipe II (Madrid: Ediciones Alpuerto, 1994), 9.

${ }^{7}$ Henry Kamen, El enigma del Escorial (Madrid: Espasa Calpe,2009), 71.

8 Almudena Pérez de Tudela, "El Alcázar de Madrid y los Sitios Reales en la visita del Duque de Saboya de 1591", en La extensión de la Corte. Los Sitios Reales, ed. Concha Camarero y Félix Labrador (Madrid: Universidad Autónoma de Madrid, 2017), 187.

${ }^{9}$ Padre Fray José de Sigüenza, Historia primitiva y exacta del Monasterio del Escorial. La más rica en detalles que se ha publicado. Escrita en el siglo XVI por el Padre Fray José de Sigüenza. Bibliotecario del Monasterio y primer bistoriador de Felipe II, arreglada por D. Miguel Sánchezy Pinillos, ed. Miguel Sánchez Pinillos (Valladolid, Maxtor, 2001), 33-34. 
destemplanza, entibiasen los propósitos y se dilatasen hasta que con muchos sucesos se pusieran en olvido. Los religiosos y siervos de Dios, entendiendo estos designios, o los sospecharon como gente experimentada en estos combates, animaron a los que iban con ellos, y el santo fray Juan de Colmenar, que iba por como capitán ó adalid de este escuadrón, dijo en voz alta a todos los que iban con él; «esta tempestad despierta el demonio para que desmayemos o para engañarnos; mas no ha de sacar de ella ningún fruto; pasemos adelante y no hagamos caso de su malicia Animados con esta voz llena de fe y espíritu, subieron hasta el mismo sitio, y amansó mucha parre del aire.

La extensa cita recoge muchas de las teorías esotéricas y pseudoacadémicas que desgraciadamente siguen rodeando a tan magnífica construcción, enturbiando su verdadero sentido que, como veremos, nada tiene que ver con ello. Fue Fray José de Sigüenza el que vinculó el enclave con el demonio y no el rey, pues en ningún documento, y Felipe era muy dado a ello, lo consigna de tal manera.

No sabemos si el fraile lo hizo como figura retórica para engrandecer la obra de su rey o siguiendo las leyendas que desde la Edad Media acompañaban al sitio. Lo que sí que podemos saber, interpretar, es que el monarca era poco dado a creer tales historias como refleja el mismo Fray José de Sigüenza, pues ante tales "vientos infernales", Felipe escribió al mismo que «...no se espantasen del aire y tempestad que había hecho, porque también en Madrid había sido día muy áspero y de grandes aires» ${ }^{10}$.

La respuesta apegada a la realidad del monarca no evitó que leyendas e historias fantásticas se adhirieran a sus muros de manera imperecedera. Posiblemente, y sorprende que aún hoy sea así, la que más fuerza tenga sea la del gran perro negro de San Lorenzo, que aullaba en las frías noches del Escorial. Vuelve a ser Fray José de Sigüenza el que nos informe que simplemente se trataba de un perro perdido, que entre aullidos lastimeros buscaba a su amo, lo que aterrorizó a muchos. El animal terminó siendo colgado por dos frailes a las puertas del claustro para que los feligreses vieran el origen de los aullidos que les atemorizaron por la noche:

comenzaron a decir los peones $[. .$.$] que andaba de noche en esta fábrica un perro$ grande y negro, con unas cadenas arrastrando, que de cuando en cuando, daba unos aullidos temerosos; fue creciendo la fama, y aunque la gente de algún seso se reía de esta niñería, otros de menos caudal o más malicia la alentaban, fingiendo cuentos y vistas de tal suerte, que voló por todo el reino, y apenas se hablaba de otra cosa, sino del perro negro de San Lorenzo' ${ }^{11}$.

Sin lugar a dudas, el equívoco que más se ajusta a nuestros intereses del presente estudio es el que vincula el monasterio escurialense con el mítico Templo de Salomón, inexactitud que no solo se produce entre los amantes de lo esotérico sino, más preocupante, entre algunos trabajos académicos. Recordemos que Manobel se ayudaba en sus actos mágicos por un grimorio, libros de magia que se conocían

\footnotetext{
10 Sigüenza, Historia primitiva y exacta, 35.

${ }^{11}$ Sigüenza, Historia primitiva y exacta, 121.
} 
popularmente como "clavículas", vinculadas al mítico rey Salomón en su calidad de mago. ¿Podría haber elegido Manobel los bosques del Escorial por este motivo?

La primera referencia que tenemos del Escorial como Templo de Salomón procede de la obra del jesuita cordobés Juan Bautista de Villalpando. Éste colaboraba con el también jesuita Jerónimo Prado en un estudio textual del Libro de Ezequiel, concretamente en los capítulos dedicados al templo de Salomón. Cuando Prado murió en 1595, le correspondió a Villalpando rematar el escrito Así, en 1596 publicaría In Ezechielen explanationes et apparatus urbis ac templi Hierosolymitani, casi todo salido de la pluma de Prado, siendo los tomos de 1604 trabajo de Villalpando. Es de resaltar que cuando Villalpando publicó su volumen, el monasterio estaba totalmente acabado y Felipe II había muerto. Por tanto, es muy difícil vincular influencia alguna del tratado de Villalpando con el Escorial e imposible en el caso de Manobel, que llegó al Escorial casi quince años antes.

A pesar de ello hay muchos autores que aún hoy día sugieren tal semejanza basándose en la relación entre Villalpando y Juan de Herrera como discípulo y maestro, llegando incluso a proponer que el propio Villalpando enseñó sus planos al rey en $1580^{12}$ a pesar de que no tenemos pruebas que certifiquen este último extremo ${ }^{13}$. En cualquier caso, y como Arias Montano ya se apercibió en su momento, el paralelismo no podría establecerse entre el verdadero templo de Salomón y El Escorial, sino entre el templo de Salomón que Ezequiel vio en sus visiones y la obra de Felipe. De cualquier modo y como ya hemos consignado, el paralelismo entre el templo del Escorial y el del rey bíblico se estableció cuando monarca ya había fallecido. Kamen lo asevera de la siguiente manera ${ }^{14}$ :

En España, la identificación de Felipe con Salomón se realiza apenas una generación después de la existencia del Escorial, y con el propósito claro de establecer una comparación piadosa más que de insinuar que el rey deseaba en realidad crear una versión actualizada del templo de aquel.

Desgraciadamente, todo este halo misterioso ha ocultado la verdadera magnitud de la obra de Felipe II. En primer lugar, su valor artístico, en el que el rey volcó todo lo aprendido en su "Felicísimo viaje"15 por toda Europa entre 1548-1551.

12 Así lo sugiere, por ejemplo, Pedro Martín Gómez, El Escorial. El cielo en la tierra (Madrid: Torreblanca ediciones, 2010), 62. Para ello se basa en el trabajo de René Taylor, Arquitectura mágica. Consideraciones sobre la idea de El Escorial (Madrid: Siruela, 2006). Esta teoría sigue reformulándose una y otra vez de manera acrítica, como demuestra el libro de Ricardo Aroca, Edificios mágicos (Madrid: Espasa Calpe, 2014), 205.

${ }^{13}$ Henry Kamen, El enigma del Escorial (Madrid: Espasa Calpe, 2009), 126.

${ }^{14}$ Kamen, El enigma del Escorial, 121.

${ }^{15}$ El relato del mismo lo podemos encontrar en la obra de: Juan Cristóbal Calvete de Estrella, El felicissimo viaie del mvy alto y mvy poderoso principe don Philippe, hijo del emperador don Carlos Quinto Maximo, desde España a sus tierras de la baxa Alemaña: con la descripcion de todos los Estados de Brabante y Flandes. / Escrito en quatro libros por Iuan Christoual Calvete de Estrella (Anvers: en casa de Martín Nucio, 1552). 
El interés de Felipe por la arquitectura y su amor por el $\operatorname{arte}^{16}$ está fuera de toda duda, representando El Escorial la cumbre del clasicismo internacional del siglo XVI ${ }^{17}$. En él se aúnan elementos de vanguardia renacentista italiana, elementos constructivos propios de la tradición española, así como os tejados de los Países Bajos, configurando un arte tan personal que se ha etiquetado como estilo austriaco, sinónimo de la monarquía Habsburgo española.

Su impresionante arquitectura no nos debe ocultar el papel del Escorial como fuente de ciencia y saber, donde el rey se esforzó en reunir una biblioteca que aún hoy asombra al visitante. Además, fue uno de los más importantes centros de estudio de medicina con su imponente botica ${ }^{18}$ a la que llegaban hierbas de todos los rincones de su imperio. Igualmente fue centro de ciencias experimentales con un instrumental científico de enorme valor y, en fin, núcleo de cultura y saber. Como contrapunto, rodeando este centro de saber y arquitectura renacentista, el ignoto bosque de la Sierra de Guadarrama.

\section{EL ACTO MÁGICO DEL NIGROMANTE JAIME MANOBEL}

\subsection{El bosque y la bruja}

Atraído por las leyendas medievales del Escorial, Manobel llevará a su paciente a su bosque. Decía el maestro Caro Baroja ${ }^{19}$ que "El Mal tiene su escenario propio: la noche”, pudiendo añadir más específicamente que es la noche en lo más profundo del frondoso bosque. Siguiendo a Bartra ${ }^{20}$ podemos retratar el bosque como una inmensa reserva donde aún late el eco de lo maravilloso y lo mágico, donde se asientan los "lugares sagrados" más arcaicos ${ }^{21}$. Una frontera real e imaginaria en el cual se han refugiado las creencias paganas y sus dioses, ahora considerados personajes diabólicos que acechaban bajo la espesura arbolada a la sociedad cristiana. Un portal sobrenatural hacia un mundo dual en el que se entremezcla temor y adoración, "un lugar que transmite temor y, por ende, respeto, pero al mismo tiempo es evocador y bello"22.

El bosque no es un lugar en absoluto deshabitado. Bartra, siguiendo al maestro Bloch, enumera un mundo inquietante de "bosqueros" (boisilleurs), vagabundos de los bosques a los que hay que unir a toda suerte de prófugos de la justicia, bandas de

\footnotetext{
${ }^{16}$ Agustín Bustamante García, La octava maravilla del mundo: Estudio histórico sobre el Escorial de Felipe II (Madrid: Ediciones Alpuerto, 1994), 17.

${ }^{17}$ Jesús Escobar, La Plaza Mayor y los orígenes del Madrid Barroco (Madrid: Nerea, 2007), 39.

18 Sobre la botica del monasterio podemos encontrarlo en: Mar Rey Bueno, "El funcionamiento diario de Palacio. La Real Botica", en La Corte de Felipe IV (1621-1665): Reconfiguración de la Monarquía católica, vol. I, eds. José Martínez Millán y José Eloy Hortal Muñoz (Madrid: Polifemo, 2015), 507-560.

${ }^{19}$ Julio Caro Baroja, Las brujas y su mundo (Madrid: Alianza, 1969), 44.

20 Roger Bartra, El mito del salvaje (México: Fondo de Cultura Económica, 2011), 90-93.

${ }^{21}$ Mircea Eliade, Tratado de historia de las religiones. Morfología y dialéctica de lo sagrado (Barcelona: Círculo de Lectores, 1991), 278-279.

${ }^{22}$ Lucía Triviño Guerrero, "Imaginando entre árboles: un recorrido a través del bosque simbólico", La cultura del árbol 76 (2016): 32.
} 
asaltantes, lunáticos o locos. Este espacio natural se erige frente al civilizado como alegoría de lo salvaje y de lo irracional.

Como bien nos han enseñado la mitología y los cuentos tradicionales en el bosque se esconde el mal, la muerte y toda suerte de mujeres malvadas tales como las brujas, que atormentaban a los hombres con enfermedades como la que sufría Leal, la impotencia. Nos encontramos con uno de los maleficios más comunes que realizaban las brujas con ayuda de los diablos. Así podemos leerlo en la cuestión VIII titulada «¿Pueden los diablos impedir la potencia genital?»», en el célebre Martillo de las brujas o Malleus meleficarum (1486) de los dominicos Sprenger y $\mathrm{Kramer}^{24}$. Estos incluso se atrevieron a proponer soluciones a ello en el capítulo dos, titulado "Remedios para aquellos que han sido embrujados en cuanto a su potencia genital" ${ }^{25}$, cuyo primer párrafo explica a la perfección porqué son los hombres los más afectados por tal maleficio y cómo es el demonio el que por medio de las brujas lo propaga:

Las mujeres que son brujas son mucho más abundantes que los hombres, como se ha demostrado en la primera parte. Pero los hombres son embrujados con preferencia. La razón es esta: mucho más que sobre el resto de los actos humanos, Dios permite el maleficio sobre el acto venéreo a través del cual se produce la propagación del primer pecado. Igualmente el maleficio tiene lugar primordialmente por medio de las serpientes que obedecen mucho más dócilmente a los encantamientos por haber sido el primer instrumento del diablo. Ahora bien el acto venéreo es mucho más fácil de embrujar en el hombre que en la mujer. Luego [...] Como ya se ha visto realmente existen cinco maneras para que el demonio actúe sobre la potencia genital y estos medios resultan más eficaces entre los hombres ${ }^{26}$.

En el caso que nos ocupa la impotencia de Leal no es achacada a una bruja en concreto, sino al indeterminado colectivo de las brujas, "un colectivo misterioso e indefinido y, desde luego, no asociado a ninguna persona en concreto" ${ }^{27}$. En la impotencia de Leal, muy probablemente, se escondían conflictos enmascarados con su pareja. Estos, antes como ahora, eran habituales y más en una época marcada por las dificultades para tener relaciones sexuales satisfactorias ${ }^{28}$. Esto suele ser habitual en las relaciones de pareja, en la que los legajos inquisitoriales en muchas ocasiones dejan ver una absoluta falta de comunicación que no pocas veces desembocaba en violencia psicológica e incluso física. Como dice la propia Tausiet ${ }^{29}$ :

${ }^{23}$ H. Sprenger y Kraemer, El martillo de las brujas. Para golpear a las brujas y sus herejías con poderosa maza (1486), ed. Miguel Jiménez Monteserín (Valladolid, Maxtor, 2004), 121-127.

${ }_{24}$ Un buen estudio sobre esta obra podemos encontrarlo en: María Jesús Zamora Calvo, "Kramer, Sprenguer y sus seguidores en la Europa católica." en Science, magie et religion, un compromis médiéval (Valenciennes: Presses Universitaires Valenciennes, 2005), 129-146. Más reciente María Jesús Zamora Calvo, Artes Maleficorum. Brujas, magos y demonios en el Siglo de Oro (Barcelona: Calambur), 2016.

25 Sprenger y Kraemer, El martillo de las brujas, 359-369.

${ }^{26}$ Sprenger y Kraemer, El martillo de las brujas, 359.

${ }^{27}$ María Tausiet, Ponzoña en los ojos. Brujería y superstición en el Siglo de Oro (Madrid: Turner, 2005), 256.

28 Tausiet, Ponzoña en los ojos, 312-313.

${ }^{29}$ Tausiet, Ponzoña en los ojos, 410. 
A la vista de los testimonios conservados en los procesos de brujería aragoneses acerca de las relaciones entre maridos y mujeres, no solo existía incomunicación dentro del matrimonio sino también, muy a menudo, una gran violencia, ya fuera física o psicológica. [...] Hay que contar, claro está, con el hecho indiscutible de los archivos judiciales no registran la armonía sino los conflictos. Con todo, aun en aquellas ocasiones en que $[\ldots]$ se intentaba transmitir un mensaje a favor de la convivencia marital, a lo sumo se aludía a una cierta "conformidad" que, en la práctica, solía traducirse en sumisión por parte de la mujer.

Esta violencia en muchas ocasiones era proyectada hacia los hijos en forma de dejación del cuidado del mismo o malos tratos que, en no pocas ocasiones, acababa con la muerte del infante. Tampoco debemos obviar el infanticidio más o menos voluntario o directo practicado por unas madres que se ven incapaces de superar la sobrecarga que conlleva un excesivo número de hijos. De esta manera más o menos voluntaria, estas mujeres se veían abocadas al abandono de los mismos, a la dejación de su cuidado hasta la muerte o a la asfixia en la noche, entre la vigilia y el sueño producido por el alcoholismo que muchas sufrían ${ }^{30}$.

Ante estas realidades inasumibles se acude al recurso imaginario de la bruja como infanticida en muchas partes de Europa y con más fuerza en España, donde parece ser su ocupación principal ${ }^{31}$. En palabras de Pilar Pedraza ${ }^{32}$ :

Así que la única virtud universalmente reconocida a las mujeres en su tiempo -y en todos-, la de su capacidad para echar hijos al mundo, viene dada la vuelta como un guante y pervertida en la abyección brujeril: la bruja cosecha niños robándolos, los ofrece al demonio para que los chupe, y hace potingues con su grasa y sus tuétanos.

De esta manera, y siguiendo a Ortiz ${ }^{33}$, la bruja se erige como espejo negativo de lo que debe ser una buena mujer. Frente a la madre reproductora dulce y buena encontramos a la vieja perversa e infértil que pondrá todas sus artes diabólicas al servicio del infanticidio y la infertilidad como la que afecta al carpintero Leal.

\subsection{La noche de San Juan}

La noche de San Juan recoge la tradición de una celebración que hunde sus raíces en cultos solares precristianos que, posiblemente, ya celebraban griegos y persas $^{34}$, vinculados al momento en que el sol alcanza su máxima latitud, el solsticio de

\footnotetext{
${ }^{30}$ María Tausiet, "Brujería y metáfora: el infanticidio y sus traducciones en Aragón (siglos XVIXVII)", Temas de Antropología aragonesa 8 (1998), 73.

${ }^{31}$ Fabián Alejandro Campagne, Strix hispánica. Demonología cristiana y cultura folklórica en la España Moderna (Buenos Aires: Prometeo Libros, 2009), 53.

32 Pilar Pedraza, "Brujería y abyección", Roma: Atti del XIX Convegno [Associazione ispanisti italiani], coords. Antonella Cancellier y Renata Londero (Padova: Unipress, 2001), 8.

33 Alberto Ortiz, Tratado de superstición occidental (México: Universidad Autónoma de Zacatecas, 2009), 152.

34 J. M. Iribarren Rodríguez, "El folklore del día de San Juan”, Príncipe de Viana 3 (1942): 201-2017.
} 
verano. El cristianismo creó en torno a ellos su propia alegoría vinculando al último profeta del Antiguo Testamento, Juan el Bautista, con el solsticio de verano el decrecimiento solar, en oposición al solsticio de invierno, que es cuando el astro rey crece, momento que se vincula a Cristo como proclama orgulloso el Pantócrator de San Clemente de Tahull "Ego sum lux mundi".

De la misma manera, debemos entender la celebración del solsticio de verano como rito de paso, de muerte, vida y resurrección. Cita clave para las potencias celestiales y demoniacas, donde los hombres intentan protegerse invocando a las primeras y ambicionan someter a las últimas. Noche de purificación por medio del fuego que se encendían en torno a un árbol podado o "mayo" adornado con flores, fuegos que Jacopo de Vorágine dice que se prenden para espantar a los dragones o demonios que ponen en peligro la fertilidad de la tierra. Demonios que se pretenden conjurar por medio de peregrinaciones con carácter de exorcismo, en una noche que la Iglesia asocia a una magia peligrosa que no puede controlar ${ }^{35}$. En palabras de Lisón Tolosana ${ }^{36}$ : "Brujas, fantasmas. Ánimas, demos y encantos merodean, pues, sin trabas esa extraña noche, obrando según requiere la inclinación de su propia naturaleza". Momento del año donde los demonios, ayudados por brujos y brujas, desplegarán una gran actividad como refleja la propia Inquisición ${ }^{37}$ :

En la noche de San Juan, después de acabadas las dichas ceremonias, va el Demonio con todos los brujos a la iglesia y, abriéndoles las puertas, se queda él fuera y los brujos hacen muchas ofensas y ultrajes a la Santa Cruz y a las imágenes de los santos.

Noche donde fuego, humo, agua y plantas tocadas por el primer rocío cobran propiedades mágicas que muchos se aprestan a aprovechar sobre todo para la salud y la fertilidad en todas las vertientes imaginables. Noche poliédrica y ambigua cuya complejidad se resiste a quedar atrapada entre palabras, siendo la descripción de Francisco Santos en su obra La tarasca del parto en el mesón del infierno y días de fiesta por la noche ${ }^{38}$ de 1671, el texto que más cerca ha estado de encerrar el citado espíritu carnavalesco, demoniaco, mágico y mítico de San Juan, cuyas hogueras aún refulgen en el siglo XXI:

Difponte à la pintura de la noche de San Iuan, fiefta tan celebre en todo el mundo, pues el Catalogo de Argel la pregona por fanta. Bien merecido de aquel primo de Chrifto, fantificado en el vientre de fu madre, y Pregonero de las grandezas de Dios, y pues yà và anocheciendo efte dia veinte y tres de Iunio, vifpera de tã feftiuo alboroço,

\footnotetext{
35 Philippe Walter, Mitología cristiana. Fiestas, ritos y mitos de la Edad Media (Buenos Aires: Paidós Diagonales, 2004), 129-143.

${ }^{36}$ Carmelo Lisón Tolosana, Brujería, estructura social y simbolismo en Galicia (Madrid: Akal, 2004), 62.

37 "Carta de los inquisidores a Felipe III (Logroño, 31 de octubre de 1610), AHN. Inquisición, Lib.835, 343 r. y sig", en The Salazar Documents. Inquisitor Alonso de Salazar Frías and Others on the Basque Witch Persecution, ed. Gustav Henningsen (Leiden-Boston: Brill, 2004), 125.

${ }^{38}$ En la cita sigo la edición de: Elisa Isabel Melero Jiménez, "Edición crítica de la Tarasca de parto en el Mesón del Infierno y días de fiesta por la noche" (Tesis doctoral, Universidad de Extremadura, 2013), p. 389.
} 
hora en que hemos de empezar à manifeftar (tu con tu pluma, y yo con el difcurfo defengañado) la maquina Real de tantas baratijas como fe manejan efta noche, y la pintura de las fimples, tan fin numero, que fe creen del acafo de lo que oyen, ven, òimaginan, andando vigilante en eftas ocafiones el demonio, por perturbar almas, ò enredarlas entre los futiles laços de fu habilidad, que como perdiò la gracia, procura que otros la pierdan, dando credito a cofas que no lo merecen, pues folo Dios es el dueño todo, a quien fe debe honor, y gloria, y no a cofas fuper[ticiofas, y hechiçeras ${ }^{39}$.

Con lo anteriormente expuesto podemos entender la necesidad de Manobel $^{40}$ de celebrar el ritual en el bosque. Para someter al diablo y a su secuaz la bruja, es necesario hacerlo allí donde las potencias maléficas son más poderosas. Manobel y Leal nos relatan el acto mágico de manera separada en sendas audiencias inquisitoriales que, posteriormente, fueron unificadas en por el inquisidor Licenciado Sotocameno, relato que es el que utilizamos en el presente estudio al ser el más completo.

Antes de proceder al ritual, era necesario contar con roquete, estola y agua bendita, por lo que Leal propone a Manobel visitar a un vecino suyo de Valdemoro, Antón Sánchez, que es el mayordomo de la enfermería de San Lorenzo, para que les facilite dichos elementos. El encuentro entre los antiguos convecinos es cordial, ambos se preguntaron por sus respectivas vidas y Leal le cuenta a Sánchez su dolencia y la necesidad de hacerse con los elementos religiosos antes citados. Como relató ante el tribunal el propio Sánchez: "y éste que declara se la dio, pensando que hacía buena obra, como le dijo que era clérigo y que sería para hacer algún conjuro como otras veces lo había visto hacer." ${ }^{\prime 11}$

Así pertrechados y hacia las 11 de la noche, el clérigo nigromante comenzó el ritual mágico pintando en el suelo un círculo con un clavo donde sitúa al enfermo al que impregna con cera de una vela en manos, boca y pies que después debe dejar encendida hasta consumirse en la misa de San Juan. Mientras, el clérigo recitaba lo que decían ser evangelios, al tiempo que le rocía con agua bendita y el enfermo recita credos. La ceremonia, de unas tres horas de duración, continúa con Leal subiendo y bajando tres veces de un caballo que llevaron a tal efecto y subiendo y bajando, de nuevo, esta vez de un árbol. Cuando ha terminado con Leal, el nigromante pinta otro círculo en el suelo para extender un lienzo donde recogerá el grano del helecho, acto tras el cual se echaron a dormir en el mismo escenario de la ceremonia.

Entretanto, en el monasterio de San Lorenzo del Escorial, el enfermero Antón Sánchez comienza a dudar si hizo bien dejando estola y agua bendita al nigromante y

${ }^{39}$ Melero Jiménez, "Edición crítica de la Tarasca de parto" [Folio 39r/E7r]

${ }^{40}$ Como ya desarrollé en Roberto Morales Estévez, "Los grimorios y los recetarios mágicos: Del mítico Salomón al clérigo nigromante," en Señales, Portentos y Demonios. La magia en la literatura y la cultura española del Renacimiento, eds. Eva Lara y Alberto Montaner (Salamanca: Semyr, 2014), 537-554. No debe extrañarnos la presencia de sacerdotes en tareas de sanación, como dice Adelina Sarrión, Médicos e Inquisición en el siglo XVII (Cuenca: Ediciones de la Universidad de Castilla la Mancha, 2006), 17-18, un mundo complejo donde se "convivía con varias clases de "sanadores, que con sus conocimientos, académicos en unos casos, empíricos en otros y puramente supersticiosos en los demás, se ofrecían para luchar contra la enfermedad."

${ }^{41}$ AHN, Inquisición, Leg. 90/6, fol. 7v. 
asustado le pregunta a Francisco Moneiro, capellán del convento, sobre ello. Moneiro lo tiene claro, Leal y Manobel han ido al Escorial a recoger helecho, tradición mágica de la noche de San Juan, y debe recuperar inmediatamente estola y roquete. Sánchez salió a buscarles y les encuentra en la calle, pues como informaron a Antón, no habían hallado posada para pasar la noche. El enfermero les solicitó que le devolvieran la estola de inmediato, cosa que hicieron tras hacerse de rogar. Manobel le dio además la vela utilizada en el ritual con el mandato expreso que ésta arda en misa para la curación de Leal. Antón Sánchez aterrorizado se apercibe que ha sido cómplice de un acto mágico y corre a dar noticia a Fray Alonso de Santa María, prior del convento, que pone en marcha toda la maquinaria legal para que ambos vayan a dar con sus huesos en la cárcel inquisitorial, donde comenzarían a declarar el 26 de junio.

Como anunciábamos en la introducción del presente trabajo, uno de los objetivos de esta investigación era desenredar la maraña mágica, encontrar el sentido que tienen estos para nosotros extraños rituales, con el fin de introducirnos en el utillaje mental de la época, pues todos los elementos "mágicos" denotan una realidad mucho más terrenal.

\section{DESENTRAÑANDO EL LENGUAJE DEL CEREMONIAL MÁGICO. DEL CLÉRIGO NIGROMANTE AL FAÚSTICO PÍCARO BUSCAVIDAS}

Comenzaremos por identificar al oficiante de la ceremonia, Jaime Manobel. Lo que sabemos del mismo procede de su primera declaración ante la Inquisición en julio de $1590^{42}$. Nace en el oscense pueblo de Sariñena en torno a 1556, dentro del matrimonio del calcetero Joan Manobel y María Bolea. Jaime tenía otro hermano, Pedro, que decide continuar con la tradición familiar de calceteros. No será el caso de nuestro inquieto Jaime, que con quince años marcha a Huesca a estudiar artes y cánones. Allí enfermará y, por motivos que no se explicitan en el legajo, marchará a Valencia a continuar su formación. Aún enfermo volverá a Huesca y desde allí a una pequeña ermita, donde por mandato del Obispo de Cuenca pasará veintidós meses oficiando misa, para cumplir con una promesa que entendemos que tiene que ver con la recuperación de su misteriosa enfermedad.

Manobel continuará su formación en Zaragoza, donde aprenderá las ceremonias y los sacramentos durante cinco meses, tras los cuales pasará otros siete ejerciendo como teniente del cura del arzobispado de Zaragoza. El futuro nigromante vivirá algún tiempo entre su Sariñena natal y Monegrillos hasta que se le envía a oficiar misa a un pueblo de la raya de Cataluña, donde sólo permanecerá cinco meses.

Como se puede observar idas y venidas sin que en muchos casos podamos intuir el motivo de tanto traslado. De Cataluña vuelve a Zaragoza en torno a 1590 donde permanecerá tan sólo diez meses. En este caso el motivo de su marcha precipitada sí que es relatado por el propio clérigo. Jaime se hospeda en el Mesón Carbonell, donde por medio de un capitán se entera de la existencia de un grimorio

\footnotetext{
${ }^{42}$ AHN, Inquisición, Leg. 90/6, fols. 12-14.
} 
que posee otro huésped, el monje trinitario Fray Beneditto. Jaime aprovechará la noche para robar el libro de magia al religioso y huir a Madrid con el mismo ${ }^{43}$.

$\mathrm{Al}$ abrigo y anonimato que proporciona la capital del imperio, Manobel se asienta primero en la Calle Carretas y después en la Calle de la Hoz. En el tiempo que está en la capital tratará a un tal Pablo, el legajo es parco en detalles en este punto, y a nuestro Francisco Leal, el carpintero natural de Valdemoro de veintiocho años de edad, que cree estar ligado, y que reside por aquel entonces con su mujer en la calle Mesón de Paredes.

No sabemos si con el hechizado Pablo tuvo más suerte, pero lo cierto es que los intentos de Jaime por curar a Leal no parecen tener mucho éxito. Por ello, Manobel decide pedir consejo a los amigos que tiene en la corte. Entre ellos debemos destacar a un herbolario saboyano del cual poco más sabemos. Con este último, el clérigo fue varias veces a recoger hierbas al Prado de San Jerónimo y ayudó a rellenar el grimorio de Manobel con recetas de su propia cosecha. No será el único que auxilió a completar el libro de magia del nigromante, "sino también un mozo de un barbero que vive en Madrid, junto a la casa del nuncio, como queremos salir del humilladero de San Andrés" ${ }^{44}$.

En la barbería no solo se reúnen Manobel, el mozo y el herbolario, sino que también acuden a tan curiosa tertulia dos hombres casados entre los que se intercambian recetas y hechizos para atraer mujeres o ganar en el juego. Este último extremo debía de interesar mucho a Manobel, pues las deudas que arrastraba el clérigo a cuenta de ello debían de ser cuantiosas como se desprende del propio legajo:

Dijo que se acuerda que el dicho hombre herbolario / que digo e declarado tiene. Dijo a este confesado/ que en el tiempo tiene dicho que para ganar/ el juego tomase dos huevos y que este escribiese en cada uno de ellos Deus/ Abraham devis Isaac deus xafon/ y que cuando este jugase tuviese cada un/ un huevo debajo del brazo en el hueco del/ sobaco y este lo quiso experimentar/ y escribió en los dichos huevos las dichas/ palabras y el uno de ellos se le quebró/ y por esto este no hizo la experiencia de jugar/ y no se acuerda de otra cosa que deba decirle que el dicho hombre herbolario saboyano/ solía acudir a comer al bodegón de Julio bodegonero a la puerta del Sol. 45

Este es el sucinto relato de la vida de un clérigo nigromante que, aunque al no versado en estos temas pueda parecer sorprendente y único, vamos a demostrar cómo responde a un arquetipo muy claro. Como ya se apercibió Butler ${ }^{46}$ :

me di cuenta de que todos los predecesores de Fausto, así como sus sucesores o el mismo Fausto, eran esencialmente una persona bajo diversos nombres y máscaras.

${ }^{43}$ Como ya expuse en un anterior trabajo, y siguiendo a M. J. Pedraza García, "De los libros clandestinos y nigromantes: en torno a la posesión y transmisión de grimorios entre 1509 y 1511," Revista General de Información y Documentación 17:1 (2007): 63-88; el robo de grimorios parece responder a una estrategia defensiva del nigromante ante los jueces para desvincularse de la obra mágica y así reducir la pena.

${ }^{44}$ AHN, Inquisición, Leg. 90/6, fol. 33.

${ }^{45}$ AHN, Inquisición, Leg. 90/6, fols. 45v-46r.

${ }^{46}$ E. M. Butler, El mito del mago (Madrid: Cambridge University Press, 1997), 14. 
[...] santos y pecadores; sacerdotes de ritos secretos y ocultistas; prestidigitadores, charlatanes y curanderos; todos se conducían de igual manera y sus vidas se regían por un mismo patrón.

Como habrá deducido el lector con respecto a Manobel nos encontramos ante lo que Butler calificaría de charlatán y curandero, o en palabras de Lara "se trata del nigromante embaucador, un pilluelo, un pícaro" "47. Así también lo debió entender el tribunal a tenor de la benévola sentencia que emite:

Fallamos atento lo que del presente proceso resulta contra el dicho Mosen Jaime Manobel, clérigo vecino de Sariñena Rigor de derecho hubiéramos de seguir y pudiéramos condenar en mayor y más grandes penas. Pero queriendo moderarlas en equidad y misericordia por alguna causa que hallo, nos mueven en pena y penitencia de lo por él dicho, hecho y cometido, mandamos que esta nuestra sentencia se lea en la sala de la audiencia de este Santo Oficio a do oiga misa rezada que en ella de dijese en forma de penitente y abjure de levi y sea reprendido y suspenso de las ordenes que tiene por dos años y para ello desterrado de la diócesis de esta Inquisición, lo cual se haga y cumpla con apercibimiento que sea castigado por todo rigor y por esta nuestra sentencia definitiva [...]. Dada y pronunciada fue esta dicha sentencia por los señores inquisidores que en ella firman con su nombre, estando en su audiencia de la mañana de este Santo Oficio de la inquisición de Toledo, veinte días del mes de diciembre de 1590 años, estando presente el dicho Mosen Jaime Manobel clérigo, al cual le fue notificada e dijo la consentía. Testigos, Andrés de Vargas nuncio e Francisco, portero de este Santo Oficio. ${ }^{48}$

Como buen pícaro hechicero perseguía un fin muy determinado que no era otro que conseguir riquezas ${ }^{49}$, no siendo para ello impedimento alguno su pertenencia al ámbito eclesiástico, pues Lisón Tolosan ${ }^{50}$ no duda de calificar al mismo como «bullangero contingente de ignorantes y frívolos apicarados trotamundos», lo que define perfectamente a nuestro protagonista.

No será el único, Cardini ${ }^{51}$ no dudaba en afirmar que el mundo de la magia y la medicina popular era "terreno de los "magos" y de los "médicos" vagabundos, de los falsos clérigos y de los falsos mendigos». Como asevera Tausiet un, buen número de nigromantes eran clérigos, monjes o personas relacionadas con la esfera religiosa ${ }^{52}$. Es precisamente el propio ritual de la Iglesia, con su ingente cantidad de fórmulas para luchar contra el demonio la que da al clérigo su poder. ¿Quién mejor que ellos para invocar a las potencias infernales y dominarlas? Nadie, salvo los hombres de Iglesia tienen a mano los elementos consagrados que se utilizan en multitud de ritos y solo ellos pueden bendecirlos.

\footnotetext{
47 Lara, "Hechiceras celestinescas", 407.

48 AHN, Inquisición, Leg. 90/6, fol. 96.

${ }^{49}$ María Tausiet, Ponzoña en los ojos. Brujería y superstición en el Siglo de Oro (Madrid: Turner, 2005), 489.

${ }^{50}$ Carmelo Lisón Tolosana, Brujería, estructura social y simbolismo en Galicia (Madrid: Akal, 1990), 14.

${ }^{51}$ Franco Cardini, Magia, brujería y superstición en el Occidente Medieval (Barcelona: Península, 1982), 129.

${ }^{52}$ Tausiet, Ponzoña en los ojos, 489.
} 
¿Podría aducirse que los autores citados son por sus apreciaciones anticlericales? Parece poco probable tal extremo a la luz de las declaraciones del muy poco sospechoso por anticlerical, Fray Martín de Castañega $(1529)^{53}$ :

Por experiencia vemos cada día que las mujeres pobres y clérigos necesitados e codiciosos, por oficio toman de ser conjuradores, hechizeros, nigrománticos y adivinos por mantener e tener de comer abundosamente; y tienen por esto las casas llenas de concurso de gentes.

En cuanto al propio término "nigromante" Pedraza García asevera ${ }^{54}$ que es de

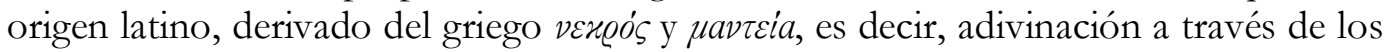
muertos, práctica, rastreable desde la Antigüedad ${ }^{55}$ y de la que Ciruelo (1551) nos da noticia ${ }^{56}$ :

El primero que halló la arte mágica (que en griego se llama «nechromancia», en español nigromancia) fue Zoroastres en Persia. Y después sucedió a él. Balaam, aquél a quien habló su asna cuando venía conducido para encantar el pueblo de Israel: y dende a luengos tiempos, de aquella tierra y seta, según dice San Agustín, vinieron los Magos a Jerusalén para adorar a nuestro señor Jesucristo recién nacido, guiados por la estrella, etc. Aquella arte en tiempos pasados se ejercitó en nuestra España, que es de la misma constelación que la de Persia: mayormente en Toledo y Salamanca.

En la Edad Media el término se hizo sinónimo de magia negra o diabólica y nacía así de manera embrionaria la asimilación de la nigromancia con la hechicería de carácter menos culto ${ }^{57}$. Al respecto Ciruelo ${ }^{58}$ arguye sin dudar que: «A esta nigromancia pertenece el arte que el diablo a enseñado a las brujas o xorguiñas, hombres o mujeres, que tienen hecho pacto con el demonio.» La otrora magia alta del mago o nigromante, al ser éste víctima de un engaño por su ignorancia, se pone al mismo nivel que la bruja o xorguiña. No por ello se atribuye a sus compañeros hombres el apelativo de brujos ${ }^{59}$, ni siquiera de hechiceros, sino nigrománticos como podemos leer en el Tratado de las supersticiones de Castañega (1529) ${ }^{60}$ :

\footnotetext{
${ }^{53}$ Castañega, Tratado de supersticiones, 13 , fol. $7 \mathrm{v}$.

${ }^{54}$ M. J. Pedraza García, "De los libros clandestinos y nigromantes: en torno a la posesión y transmisión de grimorios entre 1509 y 1511”, Revista General de Información y Documentación, 17 (1) (2007),

${ }^{55}$ Uno de los muchos trabajos dedicados al tema es: Pilar Gómez i Cardó, "Voces del Hades, decretos del Más Allá: la consulta de los muertos en Luciano.” Revista de Estudios Clásicos, 43 (2016): 97 -

56 Pedro Ciruelo, Reprobación de las supersticiones y hechicerías: libro muy vtil y necesario a todos los buenos christianos, 1551. ed. Francisco Tolsada (Valladolid, Maxtor, 2005), 35.

${ }^{57}$ Sebastiá Giralt, "Magia y ciencia en la Baja Edad Media: la construcción de los límites entre la magia natural y la nigromancia, c. 1230 - c. 1310”, Clío y Crimen 8 (2011), 37.

${ }^{58}$ Ciruelo, Reprobación de las supersticiones y hechicerías, 136.

${ }^{59}$ Lara, "Hechiceras celestinescas", 405.

${ }^{60}$ Castañega, Tratado de las supersticiones, 19-21.
} 65. 128. 
Mas las mujeres, como no tienen escusa por alguna arte o ciencia, nunca las llaman nigrománticas [...] saluo megas, bruxas, hechiceras, xorguiñas o adeuinas», mientras «los hechizos que los hombres hacen, atribuyense a alguna sciencia o arte e llamalos el vulgo nigrimanticos e no los llama bruxos.

Hasta mediados del siglo XIV se considera que el nigromante es engañado por el diablo simulando que el primero le controla, a la vez que se duda de la realidad de sus operaciones. Cuando Tomás de Aquino formule de manera canónica la idea de pacto demoniaco, el mago pasará a ser un esbirro del dominio a las órdenes del mismo, motivo por el cual el nigromante será juzgado por herejía. Ciertamente no fue un concepto nuevo, sino que tiene un proceso de formación que podemos rastrear en obras como la del médico Arnau de Vilabona De reprobaciones ficcionis nigromantice, donde se califica a la magia diabólica como engaño, línea que sigue Roger Bacon en la Epistola de secretis operibus artis et de nullitae magie $e^{61}$.

Sintomáticamente, es en la Edad Media cuando se produce un momento clave en la creación del arquetipo del nigromante y la hechicería, así como de leprosos o judíos. Son los marginados por la creciente división social y el inicio de la economía monetaria en marcha desde el siglo $\mathrm{XI}^{62}$, lo que precederá a las hogueras de la caza de brujas en la Edad Moderna. En cuanto al arquetipo de nigromante es, como decíamos al principio, de carácter literario y muy similar en sus múltiples máscaras. Butler comienza el capítulo dedicado a Fausto de la siguiente manera ${ }^{63}$ :

Es posible afirmar sin reservas que fue a un mundo corriente, y en concreto a su estrato más bajo, al que el verdadero Fausto perteneció: así lo atestigua su preferencia por las tabernas alemanas $[\ldots]$ caldo de cultivo para sus estúpidas supercherías y trucos picarescos asociados al verdadero Fausto, cuya fama, de no ser por su desmedida fanfarronería, buen podría haberse reducido a polvo.

Lara, al igual que Butler, no se apiada del nigromante al que retrata como un actor exagerado; "es un profesional de la mentira, un estafador que maneja el arte de la performance [...] La esencia de su existencia es la interpretación" ${ }^{64}$. Manobel no parece ser distinto, de taberna en posada y de posada en taberna jugando a las cartas y robando según sus necesidades.

Fausto y Manobel sugieren un arquetipo que, en el caso del primero, dio el salto a la fama en la literatura universal con la obra La trágica historia del doctor Fausto (1604) de Cristopher Marlowe, y que Goethe elevó a mito literario decimonónico cuando entregó la segunda y última parte de su Fausto en 1832. La literatura española no se quedó atrás con títulos como El mágico prodigioso (1647) de Calderón de la Barca, quizá la obra más conocida de un elenco que podría incluir Comedia erudita (1547) de Sepúlveda u obras de Joan Timoneda como Comedia Cornelia (1559), la Farsa Paliana,

\footnotetext{
61 Giralt, "Magia y ciencia”, 56.

${ }^{62}$ Giralt, "Magia y ciencia", 36.

${ }^{63}$ E. M. Butler, El mito del mago (Madrid: Cambridge University Press, 1997), 166.

${ }^{64}$ Lara, "Hechiceras celestinescas", 411-412.
} 
la Comedia Aurelia de la o Farsa Floriana, todas escritas entre $1564-1565^{65}$. En palabras de Gari: "gran parte de las manifestaciones de la brujería han tenido su expresión a través de la literatura" ${ }^{66}$. Y éste es un viaje de ida y vuelta, pues como demostraron Zamora Calvo ${ }^{67}$ y Ortiz $^{68}$, el propio discurso antimágico está empapado de literatura.

\subsection{Elpacto diabólico en la noche de San Juan}

El pacto diabólico es la idea central del concepto acumulativo de brujería ${ }^{69}$. Este concepto, que ya se puede rastrear en los escritos de San Agustín, se difundió por Europa a partir del siglo IX en forma de leyendas. La idea de pacto diabólico es un arquetipo literario surgido en la Edad Media, pero que mutará del anónimo pecador que se salva in extremis por la intervención de Dios o la Virgen, al Fausto renacentista cuya historia se reinterpretará de manera permanente ${ }^{70}$. Se trata de un "micro relato fantástico que sintetiza el encuentro concertado del hombre y el mal en circunstancias mágicas" $" 71$.

En torno a los siglos XII y XIII se produjo una llegada masiva de libros de magia islámicos y griegos que tuvo como consecuencia la práctica del conjuro y control de demonios llamada necromancia, a pesar de que esto significara evocación de los espíritus muertos, magia que el escolasticismo trató como herejía. Cuando el delito se dirigió hacia el pueblo llano, como hemos visto, haría del otrora poderoso mago un ignorante manipulado por el demonio.

Castañega en su Tratado de las supersticiones y hechicerías (1529), sigue a Santo Tomás al considera que el pacto puede ser de dos tipos. Explícito cuando invoca la ayuda del demonio o tácito cuando sin mediar conjuro de invocación demoniaca se persigue un efecto que no es natural o que no es lógico esperar de la intervención de Dios.

Los ministros de estos execramentos diabólicos son todos lo que, por pacto expreso o oculto, están al demonio consagrados y dedicados [...] El pacto expresso que se haze al demonio de sus familiares, es de dos maneras. Vno es tan expreso y claro que con palabras claras e formales, renegando de la fe, hacen nueua profession al demonio, en su presencia que les aparece en forma e figura que quiere tomar, dándole entera obediencia y ofreciéndole su ánima y cuerpo [...] Otros tienen pacto explícito y espresso con el demonio, no porque ayan hablado alguna vez con el o le ayan visto en

\footnotetext{
${ }^{65}$ Para saber más sobre el tema acudir a Lara, "Hechiceras celestinescas", 367-432.

66 Ángel Gari Lacruz, "La brujería en Aragón en la primera mitad del XVII", en Brujología: Congreso de San Sebastián: Ponencias y comunicaciones (Madrid: Seminarios y Ediciones, 1975), 43.

${ }^{67}$ María Jesús Zamora Calvo, Ensueños de la razón: el cuento inserto en los tratados de magia (siglos XVI y XVII) (Madrid: Vervuert, 2005).

68 Alberto Ortiz, "Letras del encanto. La influencia de los tratados antisupersticiosos en la literatura hispánica del siglo XVI”, en Señales, Portentos y Demonios. La magia en la literatura y la cultura española del Renacimiento, eds. Eva Lara y Alberto Montaner (Salamanca: Semyr, 2014), 201-224.

${ }^{69}$ Brian P. Levack, La caza de brijas en la Europa Moderna (Madrid: Alianza, 1995), 62.

${ }^{70}$ Pablo César Moya Casas, Los siervos del demonio (Madrid: UNED, 2000), 194-195.

71 Ortiz, "Letras del encanto", 71.
} 
alguna figura conocida, saluo con otros ministros suyos, que son otros encantadores, hechizeros o bruxos y hazen la mesmna profession que los primeros ${ }^{72}$.

Por tanto, Manobel tiene pacto explícito pues como Ciruelo asevera ${ }^{73}$ :

cualquiera cristiano que ejercita la nigromancia de cualquiera de las maneras aquí contadas, tiene pacto claro y manifiesto concierto de amistad con el diablo, y va contra el mandamiento de Dios dado a los hombres al principio de la Iglesia, y quebranta el voto de la religión cristiana que hizo el baptismo. Luego el tal cristiano es apóstata y traidor contra Dios y contra la Iglesia católica [...] Y aunque la nigromancia no sea formada herejía, es cosa muy cercana a ella y débenla castigar los inquisidores de la fe como herejía.

Bien sabía Manobel de su pacto explícito, pues como él mismo reconoce: "dice que estuvo aguardando a ver si había algún ruido de demonios y que el agua bendita llevaba para si había algo, echarla y librarse de lo que sucediese y en esto estuvo desde las diez u once horas de la noche hasta la una" ${ }^{\prime 74}$.

El nigromante va a comenzar el ritual pero antes debe protegerse con ropas ceremoniales, de ahí el interés del clérigo por la estola, como armadura de protección ante las potencias maléficas que está a punto de invocar ${ }^{75}$. Ataviado de manera conveniente, el mago comienza el ritual que él mismo relata a la Inquisición en la audiencia del seis de agosto de 1590:

Y que a las once horas de la dicha noche el dicho mosen Jaime con un clavo grande hizo un círculo redondo en el suelo y hizo a la dicha persona que decía estar ligada y hechizada tenderse en el suelo dentro del dicho círculo boca arriba y luego le puso unos pegotes de cera pez en los pies juntos, una pelotilla y en cada mano otra y en la boca otra y el dicho mosen Jaime ciertas palabras que no se entendían y decía eran evangelios y dijo al paciente que rezase tres credos y cuando estaba tendido le echaba agua bendita ${ }^{76}$.

Como podemos comprobar, la estola no es el único objeto consagrado dentro del ritual. También tenemos el agua bendita, el uso de oraciones como el credo y la utilización de elementos rituales, caso de la vela que debe arder en misa y el uso de la propia cera en el ceremonial. Elementos demoniacos mezclados con religiosos, algo que ya en 1376 codificó el inquisidor aragonés Nicolacu Eymerich como culto de dulía. Esto es, tomar a Dios como intercesor ante el demonio, distinto al culto de latría, que era rendir culto al demonio directamente.

\footnotetext{
${ }^{72}$ Fray Martín de Castañega, Tratado de las supersticiones y hechicerías y de la possibilidad y remedio dellas (1529), ed. Juan Robert Muro Abad (Logroño: Instituto de Estudios riojanos, 1994), 18-19, fols. 10r$11 \mathrm{v}$.

${ }_{73}$ Ciruelo, Reprobación de las supersticiones, 37.

${ }^{74}$ AHN, Inquisición, Leg. 90/6, fol. 41r.

75 Norman Cohn, Los demonios familiares en la Europa Moderna (Madrid: Alianza, 1987), 223.

76 AHN, Inquisición, Leg. 90/6, fol. 55.
} 
Convocar al diablo es tarea peligrosa si el oficiante no se ampara tras un círculo, espacio sagrado de protección contra las potencias infernales, que los magos copiaban de las «clavículas», libros de magia normalmente atribuidos al mítico Salomón ${ }^{77}$. Tras hacerle levantar, el ritual continúa haciéndole subir y bajar del caballo que llevaban, atravesar un cerco y hacerle subir y bajar de un árbol que Leal cree ser un roble: "y que luego le hizo levantar a la dicha persona y que subiese tres veces en el caballo que llevaron para el dicho efecto y le hizo atravesar por el dicho cerco y luego le hizo subirse en un árbol tres veces y no hacía más sino subir y bajar del dicho árbol."78

Atendiendo al primer elemento del ritual, el caballo, su multiplicidad de significantes es abrumadora al ser un arquetipo fundamental de la humanidad. Símbolo de muerte o presagio de la misma desde la Antigüedad, también es un psicopompo y vidente entre otros muchos significantes ${ }^{79}$. Evidentemente en este caso tiene otra acepción, que es la erótica, lo que explica su presencia en un ritual contra la impotencia. El caballo representa la fuerza fecundante al igual que la yegua encarna el papel de la tierra madre.

La presencia del árbol no es sorprendente, dado que la dendrolatría era habitual en la noche de San Juan ${ }^{80}$. El árbol juega un papel similar y tiene una simbología tanto o más abundante que el caballo, perdiéndose también la misma en lo más profundo de la Historia, donde los árboles eran honrados como morada de los espíritus benignos cuya sabia posee el poder de prevenir lo maligno protegiendo a aquéllos que se acercan a él ${ }^{81}$. Como recoge nuestro refranero, "A quien buen árbol se arrima buena sombra le cobija".

El árbol también se ha considerado centro del universo, como enlace entre la tierra, el cielo y el infierno ${ }^{82}$. Los árboles son manifestaciones de la divinidad y en sus hojas, tallos y troncos habitan la fecundidad, la opulencia, la suerte, la regeneración, la salud, la resurrección e incluso la inmortalidad. Este culto, como ya demostró Frazer, posiblemente sea universal allá donde existen bosques de cualquier tipo ${ }^{83}$. Recordemos que el árbol en cuestión es identificado por el carpintero como un roble, dato que nos ocioso porque, de nuevo siguiendo a Frazer ${ }^{84}$ :

La religión del roble o del dios roble parece haber sido compartida por todas las ramas del tronco ario en Europa. Lo mismo griegos que ítalos asociaron el árbol con su dios máximo Zeus o Júpiter, divinidad del cielo, de la lluvia y del trueno. Quizá el más

77 Tausiet, Ponzoña en los ojos, 495-496.

78 AHN, Inquisición, Leg. 90/6, fol. 56r.

${ }^{79}$ Jean Chevalier, Diccionario de símbolos (Barcelona: Herder, 1991), 208-216.

${ }^{80}$ Miguel Blázquez, Hechicería y superstición en Castilla la Mancha (Toledo: Servicio de Publicaciones de la Junta de Castilla la Mancha, 1985), 61.

81 Alberto del Campo y Ana Corpas, El mayo festero. Ritual y religión en el triunfo de la primavera (Sevilla: Fundación José Manuel Lara, 2005), 209-217.

82 Eliade, Tratado de Historia de las religiones, 304-305.

${ }^{83}$ James George Frazer, La rama dorada. Magia y religión (Madrid: Fondo de Cultura Económica, 2003), 142-175.

${ }^{84}$ Frazer, La rama dorada, 196-197. 
antiguo y ciertamente uno de los santuarios más famosos de Grecia fue el de Dodona, donde Zeus era reverenciado en su roble oracular.

En opinión de Caro Baroja, la dignidad del roble por encima de otras especies arbóreas pudiera basarse en expresiones religiosas y tiene su reflejo e importancia en la heráldica, pero sobre todo destaca por sus cualidades jurídicas y legales ejemplificado en el árbol de Guernica, "un símbolo superior en la vida de la colectividad" ${ }^{85}$.

El paganismo relacionaba a los vegetales con el erotismo y las fuerzas sobrenaturales. En grabados del siglo XVI podemos observar al árbol como eje central de las fiestas báquicas y aquelarres. La Iglesia censuró tal identificación proponiendo a cambio la cruz como verdadero árbol de la vida, lo que no evitó que hasta la actualidad se planten por toda Europa los árboles de mayo eso sí, cristianizados en la medida de lo posible, pues aún en muchas partes del viejo continente lo pagano y lo cristiano conviven en los celebrantes de los ritos de los árboles de mayo.

Dicha mezcla de paganismo y cristianismo podemos observarla en el grimorio de Manobel, donde se recoge una receta para proteger la salud en la que el enfermo tiene que poner su pie izquierdo en el estribo de un caballo, subir y bajar del mismo, mientras que se realizan oraciones y juramentos en torno a la resurrección y ascensión de Jesucristo:

y hallarás un caballo ensillado y enfrenado, y antes de cabalgar tiras este conjuro poniendo el pie izquierdo en el estribo conjúrote caballo por la encarnación, nacimiento, y pasión, por la muerte, resurrección y ascensión del hijo de Dios y por todas las virtudes celestiales dentro tanto tiempo sano y salvo que no dañes ni cuerpo ni alma ${ }^{86}$.

De esta manera, caballo y árbol revelan todo su significado como potenciadores de masculinidad y erotismo en el rito del Escorial en un acto de magia simpática. Manobel da por terminado el ceremonial con respecto a su paciente, pero no va a perder la oportunidad para atender a sus propios intereses con la recogida del helecho:

Aunque la noche se hacía clara y dadas las once, se tardó casi una hora en encender la lumbre y en encendiéndola le dio las doce horas y dentro del dicho círculo el dicho Jaime Manoel tenía tendido el lienzo sabana con que había cubierto a este alrededor de unas matas de helecho y con la luz miraron si habían caído algunos granos de helecho y hallaron unos granillos pequeños sobre la sabana y el dicho Jaime Manobel los cogió diciendo "estos deben ser" y dijo a este que también cogiese y se apartó [...] cabos desde dicha sábana y cogió hasta una docena de granos los cuales era como si se tomasen entre los dedos y se deshacían y este dijo que el helecho que se destruyen todos que no debe ser nada helecho y así los granos que este tenía cogidos los dio al dicho Manobel el cual los puso con los demás que él había cogido en un papel y

${ }^{85}$ Julio Caro Baroja, Ritos y mitos equívocos (Madrid: Istmo, 1989), 354.

${ }^{86}$ AHN, Inquisición, MPD, 442. Dietario mágico, fol. 33. 
estuvieron en el campo toda aquella noche hasta ya que quería amanecer que se vinieron al Escorial ${ }^{87}$.

Encontrar el significado y uso que se hace del helecho en este caso es mucho más fácil de desentrañar, pues como Blázquez asegura ${ }^{88}$ : "Dos eran las mayores tradiciones de esta noche en Castilla: curar herniados y recoger la simiente del helecho.". El helecho, como cualquier otra hierba, por sí misma no es mágica ni tiene ninguna propiedad más allá de lo que la naturaleza le confiere. Esta debe participar de un arquetipo o debe ser aislada del espacio profano por medio de palabras y gestos repetidos ${ }^{89}$. El helecho se creía útil para otras muchas cosas como por ejemplo afrodisiaco $^{90}$, para encontrar tesoros, caminar sin cansarse, tener suerte en embates de armas, o con el fin triunfar en el amor y en el juego amor y juego, extremo este último que era el que interesaba a Manobel, un tahúr sin suerte que buscaba siempre nuevas maneras de ganar.

con ocasión de que este le preguntó si sabía algún remedio para ganar al juego porque un hombre le había ganado a este muchos ducados y deseaba ganar y vengarse de él y el dicho hombre herbolario le respondió que sí había y que era el grano del helecho que se había de coger en la noche de San Juan ${ }^{91}$.

Los testimonios literarios, como el ofrecido en el libro de Francisco Santos La Tarasca del parto en el mesón del infierno y días de fiesta por la noche ${ }^{92}$ (1672), nos ayudan a constatar que la práctica de la recogida del helecho era muy habitual:

(270) YO no quifiera ferlo, amado Defengaño (dixe) y afsi te fuplico me digas, q forma tiene el elecho, digo fu grano, que las matas yà las he vifto en tierra de Segouia, que à lo lexos parecen viñas: Sabràs (me dixo) que han dado en decir [Folio 49r/Gr] los fimples del mundo que efta noche florece el grano, quaja la femilla, fecafe, y cae. Muchas cofas fe podian dezir à cerca del elecho, folo antes que fe me oluide, dirè, que me efpanto que (275) aya Chriftiano que dè credito à cofas femejantes.

Auia vn jugador en cierto Lugar, que diò credito à las palabras de vna hechiçera, la qual le diò vn grano del elecho, que fegun dizen, es como vno de alpifte, aunque otros dizen fer tan futil como el grano de la gualda, y aun menos: yo no lo he vifto en mi vida. Dixo, que en la muñeca izquierda en la parte de adentro, auia de romper el pellejo, y (280) meter el grano, y que luego èl milmo fe iba al coraçon, que eftando afsi, auia de hazer que le hizieran las mifmas exequias que à vn difunto, con fu Miffa de cuerpo prefente. Dando credito à todo, fatisfaciendo bien à la engañadora, tomò el grano que le diò, que era por la vna parte agudo, y por la otra parecia al hozico de vn puerco: efta forma defte grano la hazen afsi los que procuran engañar, folo porque [Folio

${ }^{87}$ AHN, Inquisición, Leg. 90/6, fol. 27.

88 Blázquez, Hechicería y superstición, 61.

${ }^{99}$ Eliade, Tratado de Historia de las religiones, 302.

${ }^{90}$ Melero Jiménez, "Edición crítica de la Tarasca de parto", 531.

${ }^{91}$ AHN, Inquisición, Leg. 90/6, fol. 27.

${ }^{2}$ Elisa Isabel Melero Jiménez, "Edición crítica de la Tarasca de parto”, 399. 
49v/Gv] ha dado el (285) Vulgo en dezir que tiene efta forma, fiendo todo engaño.

Rompiò en fin fus carnes, y metiò el fingido grano.

Manobel no es el único encausado por la inquisición por esta práctica mágica pues en nuestros archivos inquisitoriales descansa la causa de Diego Flórez ${ }^{93}$, vecino de Cuenca que en 1575 y acompañado por un clérigo recogía la simiente del helecho. Una vez encontrada la planta, se colocaba un paño blanco debajo de ella mientras que el clérigo con sobrepelliza y estola echaba agua bendita alrededor mientras decía: «Asperge me, Domine». Seguidamente comenzaba a leer el evangelio de San Juan combinándolo con un conjuro para aplacar tempestades mientras sostenía en una mano una vela y en la otra una cruz y una imagen de la virgen. La similitud es evidente en ambos ceremoniales, donde literatura, religión y magia se entremezclan en un baile mítico.

\section{CONCLUSIÓN}

El análisis del ritual nos ha permitido ver un mundo de creencias populares que normalmente escapa de los libros. En la tecnificada, que no científica, sociedad del siglo XXI hemos perdido todo este mundo mágico y literario de referencias, lo que nos oculta el verdadero sentir y pensar las gentes de la Edad Moderna en España.

Jaime Manobel no es un caso microhistórico que nos muestra la quiebra del discurso oficial, sino que al contrario es un participante arquetípico de la cultura popular en la España, casi me atrevería a decir en la Europa, Moderna. Tras dos trabajos intensivos dedicados a este nigromante, contamos con un modelo comparativo sólido para con el resto de magos.

La figura del mago, la utilización del círculo, el caballo o el helecho nos pone ante un universo mental que podría darnos claves para entender de manera más certera las relaciones que establecían los hombres de la Era Moderna con temas nucleares que compartimos con ellos, como la salud o el amor, pero que afrontamos con nuestros propios códigos culturales.

Igualmente, gracias al presente estudio hemos podido percibir el sentir que se tenía sobre la construcción más importante, posiblemente de toda la Edad Moderna, como lo es El monasterio de San Lorenzo del Escorial, buque insignia de los Sitios Reales. Decía Unamuno ${ }^{94}$ que al Escorial van muchos con anteojeras políticas y religiosas que desvirtúan al edificio y a su creador y que si no encontramos lo que buscamos, nos lo inventamos. Solo el estudio del Real Sitio y todo lo que lo rodeó a lo largo de su historia podrá librarnos de tales anteojeras.

${ }^{93}$ Miguel Blázquez, Hechicería y superstición en Castilla la Mancha (Toledo: Servicio de Publicaciones de la Junta de Castilla la Mancha, 1985), 65.

${ }_{94}$ Miguel de Unamuno, Andanzas y visiones españolas (1922) (Madrid: Espasa Calpe, 1975), 49. 


\section{REFERENCIAS BIBLIOGRÁFICAS}

Aroca, Ricardo, Edificios mágicos (Madrid: Espasa Calpe, 2014).

Bartra, Roger, El mito del salvaje (México: Fondo de Cultura Económica, 2011).

Blázquez, Miguel, Hechicería y superstición en Castilla la Mancha (Toledo: Servicio de Publicaciones de la Junta de Castilla la Mancha, 1985).

Bustamante García, Agustín, La octava maravilla del mundo: Estudio histórico sobre el Escorial de Felipe II (Madrid: Ediciones Alpuerto, 1994).

Butler, E.M., El mito del mago (Madrid: Cambridge University Press, 1997).

Calvete de Estrella, Juan Cristobal, El felicissimo viaie del mvy alto y mvy poderoso principe don Philippe, bijo del emperador don Carlos Quinto Maximo, desde España a sus tierras de la baxa Alemaña: con la descripcion de todos los Estados de Brabante y Flandes (Anvers: en casa de Martín Nucio, 1552).

Campagne, Fabián Alejandro, Strix hispánica. Demonología cristiana y cultura folklórica en la España Moderna (Buenos Aires: Prometeo libros, 2009).

Cardini, Franco, Magia, brujería y superstición en el Occidente Medieval (Barcelona: Península, 1982).

Caro Baroja, Julio. Las brujas y su mundo (Madrid: Alianza, 1969).

Caro Bajora, Julio. Ritos y mitos equivocos (Madrid: Itsmo, 1989).

Carvajal González, Helena. "'Cient sacras de pargamino': Un impreso 'sine notis' desconocido del taller zaragozano de Jorge Coci en el Archivo Histórico Nacional." Revista General De Información Y Documentación 29, 2 (2019): 413-425.

Castañega, Fray Martín de. Tratado de las supersticiones y bechicerías y de la possibilidad y remedio dellas (1529), ed. Juan Robert Muro Abad (Logroño: Instituto de Estudios riojanos, 1994).

Chevalier, Jean, Diccionario de los simbolos (Barcelona: Herder, 1991).

Cirac Estopañán, Sebastián, Los procesos de hechicerías en la Inquisición de Castilla la Nueva (Tribunales de Toledo y Cuenca) (Madrid: CSIC-Instituto Jerónimo Zurita, 1942).

Ciruelo, Pedro. Reprobacion de las supersticiones y hechizerias : libro muy vtil, y necessario a todos los buenos christianos (1551), ed. Francisco Tolsada (Valladolid: Maxtor, 2005). 
Cohn, Normnan, Los demonios familiares en la Europa Moderna (Madrid: Alianza, 1987.)

del Campo, Alberto, y Ana Corpas, El mayo festero (Sevilla: Fundación José Manuel Lara, 2005).

Eliade, Mircea, Tratado de historia de las religiones. Morfología y dialéctica de lo sagrado (Barcelona: Círculo de Lectores, 1991).

Escobar, Jesús, La Plaza Mayory los orígenes del Madrid Barroco (Madrid: Nerea, 2007.)

Frazer, James George, La rama dorada. Magia y religión (Madrid: Fondo de Cultura Económica, 2003).

Gari Lacruz, Ángel, "La brujería en Aragón en la primera mitad del XVII," en Brujología: Congreso de San Sebastián: Ponencias y comunicaciones (Madrid: Seminarios y Ediciones, 1975), 37-52.

Giralt, Sebastiá, "Magia y ciencia en la Baja Edad Media: la construcción de los límites entre la magia natural y la nigromancia (1230-1310)." Clío y Crimen, 8 (2011): 14-72.

Gómez i Cardó, Pilar, "Voces del Hades, decretos del Más Allá: la consulta de los muertos en Luciano." Revista de Estudios Clásicos, 43 (2016): 97-128.

Henningsen, Gustav, ed., The Salazar Documents. Inquisitor Alonso de Salazar Frías and Others on the Basque Witch Persecution (Leiden-Boston: Brill, 2004).

Hortal Muñoz, Eloy, "La integración de los Sitios Reales en el sistema de la corte durante el reinado de Felipe IV." Libros de la Corte 6(8) (2014): 27-47.

Iribarren Rodríguez, "J.M, El folklore del día de San Juan." Príncipe de Viana, 3 (1942): 201-217.

Kamen, Henry, El enigma del Escorial. El sueño de un rey (Madrid: Espasa Calpe, 2009).

Lara, Eva, "Hechiceras celestinescas y nigromantes en la literatura del siglo XVII." en Señales, portentos y demonios. La magia en la literatura y la cultura española del Renacimiento, eds. Eva Lara y Alberto Montaner (Salamanca: Semyr, 2014), 367432.

Levack, Brian, P., La caza de brijas en la Europa Moderna (Madrid: Alianza, 1995).

Lisón Tolosana, Carmelo, Demonios y exorcismos en el Siglo de Oro (Madrid: Akal, 1990). 
Lisón Tolosana, Carmelo, Brujería, estructura social y simbolismo en Galicia (Madrid: Akal, 2004).

Martín Gómez, Pedro, El Escorial. El cielo en la tierra (Madrid: Torreblanca ediciones, 2010).

Melero Jiménez, Elisa Isabel, "Edición crítica de la Tarasca de parto en el Mesón del Infierno y días de fiesta por la noche" (Tesis doctoral, Universidad de Extemadura, 2013).

Morales Estévez, Roberto, "Los grimorios y los recetarios mágicos: Del mítico Salomón al clérigo nigromante," en Señales, Portentos y Demonios. La magia en la literatura y la cultura española del Renacimiento, eds. Eva Lara y Alberto Montaner, 537-554 (Salamanca: Semyr, 2014), 537-554.

Moya Casas, Pablo César, Los siervos del demonio (Madrid: UNED, 2000).

Ortiz, Alberto, "Fórmulas pactantes. El contrato con el diablo según la tradición literario-demonologica." eHumanista. Journal of Iberian Studies, 26 (2014): 71-86.

Ortiz, Alberto. "Letras del encanto. La influencia de los tratados antisupersticiosos en la literatura hispánica del siglo XVI." en Señales, Portentos y Demonios. La magia en la literatura y la cultura española del Renacimiento, eds. Eva Lara y Alberto Montaner (Salamanca: Semyr, 2014), 201-224.

Ortiz, Alberto, Tratado de la superstición occidental (México: Universidad Autónoma de Zacatecas, 2009).

Pedraza García, M.J., "De los libros clandestinos y nigromantes: en torno a la posesión y transmisión de grimorios entre 1509 y 1511."Revista General de Información y Documentación 17(1) (2007): 63-88.

Pedraza, Pilar. "Brujería y abyección.", Atti del XIX Convegno [Associazione ispanisti italiani], coords. Antonella Cancellier y Renata Londero (Padova: Unipress, 2001), 5-18.

Pérez de Tudela, Almudena, "El Alcázar de Madrid y los Sitios Reales en la visita del Duque de Saboya de 1591," en La extensión de la Corte. Los Sitios Reales, eds. Concha Camarero y Félix Labrador Arroyo (Madrid: Universidad Autónoma de Madrid, 2017), 185-228. 
Rey Bueno, Mar. "El funcionamiento diario de Palacio. La Real Botica", en La Corte de Felipe IV (1621-1665): Reconfiguración de la Monarquia católica, Vol. I, eds. José Martínez Millán y José Eloy Hortal Muñoz (Madrid: Polifemo, 2015), 507-560.

Sarrión, Adelina, Médicos e Inquisición en el siglo XVII (Cuenca: Ediciones de la Universidad de Castilla la Mancha, 2006).

Sigüenza, Fray José de. Historia primitiva y exacta del Monasterio del Escorial. La más rica en detalles que se ha publicado. Escrita en el siglo XVI por el Padre Fray José de Sigüenza. Bibliotecario del Monasterio y primer historiador de Felipe II, arreglada por D. Miguel Sánchez, ed. Miguel Sánchez (Valladolid: Maxtor, 2001).

Sprenger, H., y Kraemer, El martillo de las brujas. Para golpear a las brujas y sus herejías con poderosa maza (1486), ed. Miguel Jiménez Monteserín (Valladolid: Maxtor, 2004).

Tausiet, María, "Brujería y metáfora: el infanticidio y sus traducciones en Aragón (siglos XVI-XVII)." Temas de Antropología aragonesa 8 (1998): 61-83.

Tausiet, María, Ponzoña en los ojos. Brujería y superstición en el Siglo de Oro (Madrid: Turner, 2005).

Taylor, René, Arquitectura mágica. Consideraciones sobre la idea de El Escorial (Madrid: Siruela, 2006).

Triviño Guerrero, Lucía, "Imaginando entre árboles: un recorrido a través del bosque simbólico." La cultura del árbol, 76 (2016): 32-38.

Unamuno, Miguel de, Andanzas y visiones españolas (1922) (Madrid: Espasa Calpe, 1975).

Walter, P., Mitología cristiana. Fiesta, ritos y mitos de la Edad Media (Buenos Aires: Paidós Diagonales, 2004)

Zamora Calvo, María Jesús, Artes Maleficorum. Brujas, magos y demonios en el Siglo de Oro (Barcelona: Calambur, 2016).

Zamora Calvo, María Jesús, Ensueños de la razón: el cuento inserto en los tratados de magia (siglos XVI y XVII) (Madrid: Vervuert, 2005).

Zamora Calvo, María Jesús, "Kramer, Sprenguer y sus seguidores en la Europa católica", en Science, magie et religion, un compromis médiéval (Valenciennes: Presses Universitaires Valenciennes, 2005), 129-146. 
Recibido: 19 de junio de 2019

Aprobado: 6 de abril de 2020 